\title{
Analisis Kandungan Asam Lemak Mudah Terbang dengan Penambahan Buah Sirih dalam Ransum Ruminansia (In-Vitro)
}

\section{Analysis of Volatile Fatty Acid Content with the Addition of Betel Fruit in Ruminants (In-Vitro)}

\author{
Nurtania Sudarmi, Widyaningrum \\ Politeknik Pembangunan Pertanian Manokwari, Jl. SPMA Reremi Kotak Pos 143 Kelurahan \\ Manokwari Barat, Manokwari-Papua Barat 98312 \\ nurtania@pertanian.go.id
}

\begin{abstract}
The area of land in West Papua is the main capital in raising cattle. Further socialization is needed regarding the importance of paying attention to the basic nutritional needs of cattle. The use of local plants that are often used by the community, such as betel fruit, is a worthy study to be explored. However, people still do not know the other benefits contained in betel fruit. In order to obtain optimal results, the study was carried out with in vitro experiments. Data processing was performed using factorial completely randomized design with three replications. The treatment factors were differentiated based on the length of the betel fruit immersion process in ice water and the length of storage time. The analysis showed that cold storage of grass with betel fruit was successful in increasing the Volattile Fatty Acid component $(P>0.01)$. The habits of the people of West Papua in utilizing local plants, especially those with tannin, have been scientifically proven to be useful. Cold storage of betel fruit with the addition of grass as ration for cattle has a very significant effect on the levels of $\mathrm{iC}_{4}$ (as iso butyrate), $\mathrm{nC}_{4}$ (as $\mathrm{n}$ butyrate), $\mathrm{iC}_{5}$ (as iso valerate), and $\mathrm{nC}_{5}$ (as $\mathrm{n}$ valerate). In addition, the Papuan people's habit of adding local plants, especially betel fruit as additional feed has been scientifically proven to be useful.
\end{abstract}

Keywords: Betel Fruit, Ruminants, Grass, In Vitro, VFA

\section{PENDAHULUAN}

Provinsi Papua Barat dalam upaya percepatan Program Utama Kementan yakni Program Sapi Kerbau Andalan (Sikomandan) telah merencanakan berbagai program, salah satunya membuat padang pengembalaan atau ranch. Kepala Dinas Peternakan dan Kesehatan Hewan Provinsi Papua Barat, drh. Hendrikus Fatem, M.P. beserta jajarannya telah menyiapkan ranch untuk menampung sapi-sapi, khususnya sapi hasil inseminasi buatan. Namun demikian, sembelum benar-benar terwujud ranch yang ada, selama ini para peternak di Papua Barat masih mengandalkan rumput alam untuk memberi makan ternaknya. 
Sapi yang tergolong ternak ruminansia mutlak membutuhkan hijauan atau bahan berserat lainnya. Keterbatasan pemahaman peternak akan mutu dan jumlah kebutuhan ransum, mengakibatkan terhambatnya pertumbuhan ternak. Selain itu, Iyai dan Sagrim (2020) menyebutkan bahwa ternak sapi di Kebar, Papua Barat cenderung disebut hama dikarenakan merusak tanaman ladang para petani.

Luasnya lahan yang ada di Papua Barat menjadi modal utama dalam pemeliharaan ternak sapi. Oleh karenanya perlu dilakukan sosialisasi lebih lanjut terkait pentingnya memperhatikan kebutuhan nutrisi dasar ternak sapi. Sebagai dasar sosialisasi, maka perlu adanya kajian bagaimana pakan yang peternak berikan di Papua Barat memberikan dampak positif bagi pertumbuhan ternak.

Pemanfaatan tanaman lokal yang sering digunakan masyarakat seperti buah sirih, menjadi kajian yang layak untuk diperdalam. Masyarakat telah terbiasa memanfaatkan pinang dan buah sirih untuk menghilangkan cacing yang bersarang ditubuh sapi. Namun masyarakat masih belum mengetahui manfaat lain yang tekandung dalam buah sirih.

Tanin yang terkandung dalam berbagai penelitian telah terbukti manfaatnya bagi ternak ruminansia terutama dalam peningkatan kandungan Asam Lemak Mudah Larut. Permasalahan yang terjadi di lapangan dengan adanya pola pemeliharaan yang diumbar menyebabkan sulitnya mengumpulkan jumlah ternak sesuai kebutuhan penelitian. Oleh karena itu, agar diperoleh hasil yang optimal maka kajian dilakukan dengan percobaan in vitro. Percobaan dengan sistem tertutup dalam tabung denagn bahan dasar rumput gajah yang digunakan masyarakat dan pemanfaatan buah sirih.

\section{MATERI DAN METODE}

Penelitian dilakukan dengan metode eksperimental. Terdapat dua tahapan dalam penelitian ini, yaitu proses penyimpanan buah sirih dan analisis kandungan Asam Lemak Mudah Terbang secara in vitro. Sampel yang disiapkan berupa ransum berbasis hijauan yang ditambahakan buah rumput gajah dan penambahan buah sirih hasil dari proses penyimpanan.

Pengolahan data dilakukan dengan menggunakan Rancangan Acak Lengkap Faktorial dengan tiga kali ulangan. Faktor perlakuan dibedakan berdasarkan dalam proses pencelupan buah sirih ke dalam air es dan lama waktu penyimpanan. Lama pencelupan terdiri dari 15 menit, 30 menit, dan 45 menit. Sedangkan waktu penyimpanan buah sirih yakni 3,6, dan 9 hari. Perlakuan yang berpengaruh nyata maka dilanjutkan dengan uji lanjut Duncan Multiple Range Test (DMRT).

Penelitian dilakukan dengan membuat formulasi sebagai berikut:

$\mathrm{R}_{1} \mathrm{~F}_{1}$ : Buah Sirih dengan penelupan 15 menit yang disimpan selama 3 hari + Rumput $\mathrm{R}_{1} \mathrm{~F}_{2}$ : Buah Sirih dengan penelupan 15 menit yang disimpan selama 6 hari + Rumput $\mathrm{R}_{1} \mathrm{~F}_{3}$ : Buah Sirih dengan penelupan 15 menit yang disimpan selama 9 hari + Rumput $\mathrm{R}_{2} \mathrm{~F}_{1}$ : Buah Sirih dengan penelupan 30 menit yang disimpan selama 3 hari + Rumput $\mathrm{R}_{2} \mathrm{~F}_{2}$ : Buah Sirih dengan penelupan 30 menit yang disimpan selama 6 hari + Rumput $\mathrm{R}_{2} \mathrm{~F}_{3}$ : Buah Sirih dengan penelupan 30 menit yang disimpan selama 9 hari + Rumput $\mathrm{R}_{3} \mathrm{~F}_{1}$ : Buah Sirih dengan penelupan 45 menit yang disimpan selama 3 hari + Rumput $\mathrm{R}_{3} \mathrm{~F}_{2}$ : Buah Sirih dengan penelupan 45 menit yang disimpan selama 6 hari + Rumput $\mathrm{R}_{3} \mathrm{~F}_{3}$ : Buah Sirih dengan penelupan 15 menit yang disimpan selama 9 hari + Rumput 
Analisis mengetahui kadar tanin buah sirih dilakukan pengujian yang di Laboratorium Penelitian dan Pengujian Terpadu Universtas Gadjah Mada, Yogyakarta. Sedangkan untuk analisis Kandungan Asam Lemak Mudah Terbang dengan peubah respon yang diamatai dan diukur: ${ }_{i} \mathrm{C}_{4}$ (as iso butirat), ${ }_{n} \mathrm{C}_{4}$ (as $n$ butirat), ${ }_{i} \mathrm{C}_{5}$ (as iso valerat), dan ${ }_{n} \mathrm{C}_{5}$ (as $\mathrm{n}$ valerat). dilakukan d Laboratorium Akreditasi Balai Penelitian Ternak, Ciawi, Bogor.

\section{HASIL PENELITIAN}

Sumber energi yang potensial untuk ternak ruminansia yakni hijauan atau bahan sumber serat yang terkandung dalam ransum ternak sapi. Hijauan yang berbentuk serta sebanyak 75 persen menyumbang karbohidrat dalam ransum ternak ruminansia. Dari total tersebut 60 hingga 75 persen akan tercerna dalam proses pencernaan fermentatif di rumen (Suwandyastuti et al., 2010).

Berbagai faktor mempengaruhi laju kecepatan atau produ metabolisme yang berbeda dari masing-masing bahan pakan. Konsumsi bahan kering, konsumsi pakan, konsumsi kimia pakan, bentuk fisik pakan, pengolahan bahan dan kondisi ternak percobaab akan memperngaruhi pola fermentasi dalam rumen.

Pengukuran produk metabolisme rumen mencerminkan aktifias metabolisme yang ada didalam rumen. Kadar iC4 (as iso butirat), nC4 (as n butirat), iC5 (as iso valerat), dan nC5 (as n valerat) yang dihasilkan menunjukkan besarnya senyawa ketogenik, glukogenik, serta besarnya laju fermentasi yang dapat menjadi dasar peternak dalam mengoptimalkan pemberian pakan pada ternaknya. Terlebih, dengan penambahan buah sirih dalam pakan menjadi gambaran untuk meyakinkan peternak apakah yang dilakukan selama ini sudah tepat atau tidak.

Tabel 1. Produk Asam Lemak Atsiri pada Percobaan In-Vitro

\begin{tabular}{|c|c|c|c|c|c|c|c|c|c|}
\hline \multirow[t]{2}{*}{ Peubah } & \multicolumn{9}{|c|}{ Perlakuan } \\
\hline & $\mathrm{R}_{1} \mathrm{~F}_{1}$ & $\mathrm{R}_{1} \mathrm{~F}_{2}$ & $\mathrm{R}_{1} \mathrm{~F}_{3}$ & $\mathrm{R}_{2} \mathrm{~F}_{1}$ & $\mathrm{R}_{2} \mathrm{~F}_{2}$ & $\mathrm{R}_{2} \mathrm{~F}_{3}$ & $\mathrm{R}_{3} \mathrm{~F}_{1}$ & $\mathrm{R}_{3} \mathrm{~F}_{2}$ & $\mathrm{R}_{3} \mathrm{~F}_{3}$ \\
\hline $\mathrm{iC}_{4}(\mathrm{mM})$ & $0,30^{\mathrm{b}}$ & $0,53^{\mathrm{de}}$ & $0,30^{\mathrm{bc}}$ & $0,76^{\dagger}$ & 0,96 & $0,28^{b}$ & $0,10^{a}$ & $0,79^{f}$ & $0,5^{d}$ \\
\hline $\mathrm{nC}_{4}(\mathrm{mM})$ & $2,25^{9}$ & $1,34^{\mathrm{b}}$ & $0,75^{\mathrm{a}}$ & $1,61^{d}$ & 3,39 & 2,69 & $1,61^{\mathrm{de}}$ & $1,56^{c}$ & $1,75^{f}$ \\
\hline $\mathrm{iC}_{5}(\mathrm{mM})$ & $0,95^{\mathrm{cd}}$ & $1,18^{\mathrm{e}}$ & $0,94^{c}$ & 1,27 & 1,66 & $0,95^{\mathrm{cd}}$ & $0,65^{b}$ & $0,52^{\mathrm{a}}$ & $1,19^{\mathrm{ef}}$ \\
\hline $\mathrm{nC}_{5}(\mathrm{mM})$ & $0,67^{e}$ & $0,77^{f}$ & $0,60^{d}$ & $0,81^{\mathrm{g}}$ & 1,56 & $0,79^{\mathrm{fg}}$ & $0,44^{b c}$ & $0,40^{a}$ & $0,44^{\mathrm{b}}$ \\
\hline Tannin (\%) & $10,38^{a}$ & $13,42^{f}$ & $13,34^{f}$ & $12,12^{d}$ & $11,64^{c}$ & 14,26 & $12,33^{\mathrm{e}}$ & $10,96^{b}$ & 13,84 \\
\hline Keterangan & & & & & & & & & \\
\hline
\end{tabular}

Tabel 1. tersaji hasil analisis Produksi $\mathrm{iC}_{4}$ (as iso butirat) tertinggi pada perlakuan $R_{2} F_{2}$ sebesar $0,96 \mathrm{mM}$ serta terendah pada $R_{3} F_{1} 0,10 \mathrm{mM}$. Begitupun dengan $\mathrm{nC}_{4}$ (as $\mathrm{n}$ butirat) tertinggi pada $\mathrm{R}_{2} \mathrm{~F}_{2}$ sebesar $3,39 \mathrm{mM}$ dan terendah $0,75 \mathrm{mM}$ pada $R_{1} F_{3}$. Nilai iC ${ }_{5}$ (as iso valerat) tertinggi ditunjukkan pada perlakuan $R_{2} F_{2}$ sebesar $1,66 \mathrm{mM}$ dan terendah pada $\mathrm{R}_{3} \mathrm{~F} 2$ senilai $0,52 \mathrm{Mn}$. Untuk $\mathrm{nC}_{5}$ (as $\mathrm{n}$ valerat) tertinggi ditunjukkan pada perlakuan $R_{2} F_{2}$ sebesar $1,56 \mathrm{mM}$, dan terendah $R_{3} F_{2}$ sebesar 0,40 $\mathrm{mM}$.

Hasil analisis menunjukkan bahwa pemberian rumput dengan buah sirih dengan penyimpanan dingin berhasil meningkatkan komponen Asam Lemak Mudah 
Terbang $(P>0,01)$ dan hasil terbaik dicapai dalam perlakuakan $R_{2} F_{2}$. Nugraha, $E$. (2003) menyebutkan bahwa kandungan Asam Lemak Mudah Terbang rumen sapi terdiri dari asam asetat, asam propionat, asam iso butirat, asam n-butirat, asam iso valerat, dan asam n-valerat. Berturut-turut \% komponen Asam Lemak Mudah Terbang sebagai berikut : 0,211;0,398; 0,099; dan 0,722.

Adanya kandungan tanin dalam buah sirih buah mampu meningkatkan nilai kandungan Asam Lemak Mudah Terbang dari masing-masing perlakuan. Meski tidak memiliki kandungan tanin tertinggi, pelakuan $\mathrm{R}_{2} \mathrm{~F}_{2}$ mengandung $11,64 \%$ kandungan tanin. Senyawa bioaktif tanin dapat dimanfaatkan untuk meningkatkan efiensi pakan yang aman bagi ternak dan lingkungan, serta mampu meningkatkan produk Asam Lemak Mudah Terbang total dan parsial (Hidayat, 2016).

Patra dan Saxena (2010) menyebutkan tanin merupakan polimer polifenolik larut air yang memiliki berat molekul relatif tinggi dan memiliki kapasitas untuk membentuk senyawa kompleks terutama protein. Kondisi ini terjadi pada tingkat yang lebih rendah dengan karbohidrat disebabkan adanya gugus hidroksil fenolat dalam jumlah besar. Tanin dibedakan menjadi dua kelompok yang terdiri dari tanin terhidrolisis dan tanin terkondensasi.

Tanin terhidrolisis merupakan polimer gallic an ellagic acid yang berikatan ester denan molekul gula. Sedangkan tanin terkondensasi merupakan polimer senyawa flavonoid dengan ikatan karbon cathecin dan gallocathecin. Hijauan yang dikonsumsi ternak umumnya membentuk tanin terkondensasi dan mempunyai ikatan kompleks dengan protein.

Ikatan komplek tersebut melindungi asam lemak rantai pendek $\left(\mathrm{C}_{2}-\mathrm{C}_{14}\right)$ dan Asam Lemak Mudah Terbang langsung diserap oleh dinding rumen. Sedangkan penyerapan asam lemak jenuh berantai panjang $\left(>\mathrm{C}_{14}\right)$ hanya terjadi di usus halus. Hal ini dapat mengoptimalkan pertumbuhan ternak yang bermanfaat bagi masyarakat.

Disisi lain, hasil penelitian menunjukkan kebiasaan masyarakat Papua Barat dalam memanfaatkan tanaman lokal khususnya yang memiliki unsur tanin, seperti pinang ataupun buah sirih telah mampu dibuktikan secara ilmiah kemanfaatannya. Awalnya masyarakat memanfaatkan tanaman ini untuk mengurangi cacing yang bersarang ditubuh ternak.

Hal ini sejalan dengan pernyataan Wigati (2010) yang menyebutkan efek tanin pada daun ketela (Manihot utilissima) berperan sebagai anthelmintik yag menghambat perkemabangan larva cacing neamatoda. Dampak lain yang ditunjukkan dengan adanya penurunan populasi cacing dewasa, menurunkan fekunditas cacing betina dewasa, dan menurunkan jumlah telur yang ada dalam feses.

\section{KESIMPULAN}

Penyimpanan dingin buah sirih dengan penambahan rumput sebagai ransum ternak sapi berpengaruh sangat nyata terhadap Kadar $\mathrm{iC}_{4}$ (as iso butirat), $\mathrm{nC}_{4}$ (as $\mathrm{n}$ butirat), $\mathrm{iC}_{5}$ (as iso valerat), dan $\mathrm{nC}_{5}$ (as $\mathrm{n}$ valerat). Selain itu, kebiasaan masyarakat Papua dalam menambahkan tanaman lokal, khususnya buah sirih sebagai pakan tambahan mampu dibuktikan secar ilmiah kemanfaatannya. 


\section{DAFTAR PUSTAKA}

Iyai, D. A. dan Sagrim, M. 2020. Profil, Input dan Output Sistem Peternakan Pada Kawasan Agro-Ekologi Tambrauw Provinsi Papua Barat. Jurnal Pertanian Terpadu 8 (1) : 1-13

Hidayat, N. 2016. Pemanfaatan Senyawa Metabolit Sekunder Tanaman (Tanin dan Saponin) dalam Mengurangi Emisi Metan Ternak Ruminansia. Jurnal Sain Peternakan Indonesia Vol. 11 No.2 : 89-98

Nugraha, E. 2003. Analisis Kandungan VFA dan LCFA dengan Menggunakan Alat Gas Kromatografi. Proseding Temu Teknis Fungsional Non Peneliti 2003. Pusat Penelitian dan Pengembangan Peternakan

Patra, A.K. dan J. Saxena. 2010. Exploitation of Dietary Tanins to Improve Rumen Metabolism and Ruminant Nutrition. J Sci Food Agric Vol.91 : 24-37

Suwandyastuti, S.N.O., Rimbawanto, E.A. dan Iriyanti, N., 2010. Pengaruh Timbangan Jerami Padi, Dedak Padi dan Onggok Terhadap Kecernaan dan Produk Fermentasi Rumen Secara in vitro. J. Agripet. 10 (2) : 59-63.

Wigati, S. 2010. Senyawa Tannin sebagai Anthelmintik dan Antioksida Alamiah. Jurnal IImiah IImu-IImu Peternakan. 